\title{
Mutu layanan akademik sebagai determinan kepuasan mahasiswa
}

\section{(Academic service quality as determinant of student satisfaction)}

\author{
Nadira Martasubrata', Suwatno ${ }^{2^{*}}$ \\ ${ }^{1,2}$ Program Studi Pendidikan Manajemen Perkantoran, \\ Fakultas Pendidikan Ekonomi dan Bisnis, Universitas Pendidikan Indonesia, \\ Jl. Dr. Setiabudi, No. 229 Bandung, Jawa Barat, Indonesia \\ Email: suwatno@upi.edu
}

\begin{abstract}
ABSTRAK
Penelitian ini bertujuan untuk memperoleh gambaran mengenai tingkat mutu layanan akademik dan tingkat kepuasan mahasiswa, juga untuk menganalisis pengaruh mutu layanan akademik terhadap kepuasan mahasiswa. Penelitian ini menggunakan metode eksplanatory survey. Teknik pengumpulan data dalam penelitian ini menggunakan angket dengan model skala likert. Responden dalam penelitian ini berjumlah 348 mahasiswa salah satu universitas di Bandung. Teknik analisis data menggunakan regresi sederhana. Berdasarkan hasil penelitian, tingkat mutu layanan akademik berada pada kategori sedang, dan tingkat kepuasan mahasiswa berada pada kategori sedang. Dari hasil analisis regresi sederhana menunjukan bahwa mutu layanan akademik berpengaruh positif dan signifikan terhadap kepuasan mahasiswa. Dengan demikian lembaga perlu meningkatkan mutu layanan akademik agar kepuasan mahasiswanya pun meningkat.
\end{abstract}

Kata Kunci: mutu layanan akademik, kepuasan mahasiswa

\begin{abstract}
The aim of this research is to obtain an overview of the level of academic service quality and student satisfaction in Faculty of Economic and Business Education, also to analyze the influence of academic service quality on student satisfaction. This research used explanatory survey method. The data were obtained used questionnaire with likert scale model. The respondents in this reseach were 348 student of university in Bandung. The data was analyzed by using simple regression. The result of the data analysis revealed that academic service quality was classified as middle category, also student satisfaction classified as middle category. Based on the analyzed of simple regression, the result revealed that academic service quality has the positive and significant influence toward student satisfaction. Thus the organization need to improve academic service quality that the student satisfaction is also improve.
\end{abstract}

Keywords: academic service quality, student satisfaction

\section{PENDAHULUAN}

Dewasa ini kepuasan mahasiswa menjadi hal menarik untuk dikaji. Hal ini tidak terlepas dari peran penting mahasiswa dalam dunia pendidikan. Pendidikan adalah salah satu industri paling penting dan memaikan peran penting dalam pembangunan nasional (Dib \& Alnazer, 2013) dan ekonomi (Kundi \& Khan, 2014). Seperti halnya pendidikan, institusi pendidikan juga memainkan peran penting (Kundi \& Khan, 2014). Perguruan tinggi memiliki peran dalam pengembangan ekonomi, sosial, dan budaya (Keshavarzi \&

\footnotetext{
* Corresponding author

Copyright $(\subset)$ 2016, EISSN xxxx-xxxx
} 
Ahmadi, 2013) (Mohammadi \& Mohammadi, 2014). Di era globalisasi, kompetisi di antara institusi pendidikan di dunia pendidikan menjadi semakin ketat (Kundi \& Khan, 2014). Pada tingkat global, kompetisi di bidang pendidikan memperkuat strategi pentingnya dalam meneliti kepuasan mahasiswa (Negricea, Edu, \& Avram, 2014), mengingat perguruan tinggi memiliki orientasi pelanggan pada mahasiswanya (Khosravi, Poushaneh, Roozegar, \& Sohrabifard, 2013). Kepuasan pelanggan adalah hal penting untuk organisasi bidang layanan (Hanaysha, Abdullah, \& Warokka, 2011), pada perguruan tinggi pelanggan utamanya adalah mahasiswa (Yousapronpaiboon, 2014) (Dahan, Taib, Zainudin, \& Ismail, 2015) (Bakti \& Mestari, 2011), oleh karena itu universitas menjadi lebih sadar mengenai pentingnya kepuasan mahasiswa (Elliot \& Shin, 2002). Merupakan hal yang perlu untuk memperhatikan kepuasan mahasiswa (Keshavarzi \& Ahmadi, 2013), dalam sistem pendidikan kepuasan adalah hal terpenting (Negricea, Edu, \& Avram, 2014). Kepuasan mahasiswa penting (Hanaysha, Abdullah, \& Warokka, 2011) untuk dibahas, mengingat ada dampak positif apabila mahasiswa merasa puas (Bakti \& Mestari, 2011) seperti dalam motivasi mahasiswa, ingatan mahasiswa (Kundi \& Khan, 2014), membangun kepercayaan diri (Tuan, 2012), memberikan kata positif (Hanaysha, Abdullah, \& Warokka, 2011) komunikasi mulut ke mulut dari mahasiswa kepada teman, kenalan, dan relasi (Tuan, 2012), serta mahasiswa bersedia untuk memberikan usaha terbaik terhadap pelajaran mereka (Kundi \& Khan, 2014), dan hal tersebut akan membuat universitas memperoleh keuntungan dalam persaingan (Dahan, Taib, Zainudin, \& Ismail, 2015). Seperti yang diungkapkan oleh Mulyawan \& Sidharta bahwa kepuasan pengguna jasa dalam hal ini mahasiswa juga menjadi salah satu ukuran dari keberhasilan lembaga pendidikan tinggi dalam mengelola lembaga pendidikannya (Mulyawan \& Shidarta, 2014), dan sebagai tolok ukur dari kampus berpengalaman (Khosravi, Poushaneh, Roozegar, \& Sohrabifard, 2013), serta tetap memperhatikan mutu akademik sebagai produk jasa yang harus dicapai (Mulyawan \& Juhana, 2015).

Hasil studi pendahuluan menunjukan bahwa kepuasan mahasiswa belum optimal yang ditunjukan oleh hasil survey kepuasan mahasiswa. Mengingat kepuasan mahasiswa itu sangat penting, maka untuk menanggulangi belum optimalnya kepuasan mahasiswa, dalam penelitian ini merujuk pada teori perilaku konsumen menurut Loudon dan Della Bitta (1993). Berdasarkan teori tersebut ada beberapa faktor yang mempengaruhi kepuasan pelanggan. Menurut Negricea et al. Kepuasan mahasiswa terkait erat pada mutu layanan perguruan tinggi (Negricea, Edu, \& Avram, 2014), sehingga dijadikan kajian dalam penelitian ini.

Berdasarkan hal tersebut, masalah dalam penelitian ini adalah "adakah pengaruh mutu layanan akademik terhadap kepuasan mahasiswa?". Dengan demikian tujuan dari penelitian ini adalah untuk mengetahui ada tidaknya pengaruh mutu layanan akademik terhadap kepuasan mahasiswa.

\section{TINJAUAN PUSTAKA}

\section{Kepuasan Mahasiswa}

Secara umum, kepuasan dapat diartikan sebagai kemampuan layanan atau produk untuk memenuhi kebutuhan pelanggan (Smith, Heindel, \& Torres-Ayala, 2008). Jen \& Jung mengartikan kepuasan sebagai evaluasi emosional yang menunjukan sejauh mana pelanggan percaya bahwa penggunaan layanan dapat menghasilkan perasaan positif (Bakti \& Mestari, 2011). Kepuasan adalah perasaan senang dan kegembiraan yang individu dapat ketika kebutuhan dan keinginan mereka terpenuhi (Saif, 2014). Dengan demikian kepuasan merupakan evaluasi yang menggambarkan seseorang atas perasaan sikap senang atau tidak senang dalam beraktivitas (Susanto, 2014). 
Kepuasan mahasiswa merupakan evaluasi emosional berbagai hasil dan pengalaman yang berhubungan dengan pendidikan yang benar benar mereka peroleh dibandingkan dengan harapan mereka sebelumnya (Sumaedi, 2011). Adapun pengertian lain dari kepuasan mahasiswa adalah respon pemenuhan kebutuhan mahasiswa (Jurkowitsch, 2006). Kepuasan mahasiswa dibentuk secara terus menerus oleh berbagai hasil dan pengalaman di kampus (Seng \& Ling, 2013).

Kepuasan mahasiswa dipengaruhi oleh banyak faktor. Faktor-faktor yang mempengaruhi kepuasan mahasiswa diantaranya, Service Quality (Mutu Layanan), Image (Citra), Perceived Value (Nilai yang dirasakan) (Dib \& Alnazer, 2013). Dari beberapa faktor tersebut, dalam penelitian ini hanya akan mengkaji satu faktor yaitu mutu layanan, khususnya mutu layanan akademik. Hal ini disandarkan pada pernyataan bahwa kepuasan peserta didik merupakan tujuan dari layanan belajar di lembaga pendidikan (Suhardan, 2006).

Dalam mengukur kepuasan mahasiswa, digunakan tiga indikator, yaitu senang, share positive information, dan tidak komplain (Tjiptono, 2001), mengacu pada argumen bahwa peserta didik yang merasa puas dengan layanan belajar diberikan oleh sekolah tentunya akan menunjukan sikap yang positif disekolah (Suhardan, 2006).

\section{Mutu Layanan Akademik}

Mutu adalah gambaran dan karakteristik menyeluruh dari barang atau jasa, yang menunjukkan kemampuannya dalam memuaskan kebutuhan yang ditentukan atau yang tersirat (Ilyas, 2011). Sedangkan parasuraman mendefinisakan layanan sebagai aktivitas ekonomi yang memproduksi waktu, tempat, form atau kegunaan psikologis (Mulyawan \& Shidarta, 2014).

Mutu layanan adalah keluaran yang disampaikan dengan lebih baik dan terstandar melalui sebuah layanan (Malik, 2010). Adapula yang mengungkapkan bahwa kualitas layanan merupakan sejauh mana layanan yang diberikan oleh perusahaan sesuai dengan kebutuhan dan harapan pelanggan atau seberapa jauh perbedaaan antara kenyataan dengan harapan pelanggan atas pelayanan yang mereka terima (Mulyawan \& Juhana, 2015).

Pengertian mutu akademik adalah muara dari mutu proses pendidikan manusia, alat, kurikulum, dan fasilitas yang tercermin pada mutu mengajar dosen, mutu bahan pelajaran dan mutu hasil belajar, sehingga akhirnya membentuk seperangkat kemampuan (Alma, 2003). Menurut Sallis institusi-institusi pendidikan perlu mengembangkan sistem-sistem mutu, agar mampu membuktikan pada public bahwa institusi-institusi tersebut dapat memberikan layanan yang bermutu dan berkualitas (Triyanto \& Latnip, 2014).

Pengertian layanan akademik menurut Rosita adalah upaya sistematis pendidikan untuk memfasilitasi peserta didik menguasai isi kurikulum melalui proses pembelajaran sehingga mereka mampu mencapai kompetensi standar yang diterapkan (Susanto, 2014). Mengingat pentingnya mutu dalam institusi pendidikan, maka dikaji dalam pengertian mutu layanan akademik, dimana menurut Pakpahan kualitas pelayanan akademik merupakan perbandingan antara pelayanan akademik yang dirasakan pelanggan atau stakeholders dengan kualitas pelayanan akademik yang diharapkan pelanggan atau stakeholders (Susanto, 2014).

Mengukur kualitas pelayanan dalam konteks pendidikan tinggi bukanlah topik baru, dan sejumlah studi telah dicapai dalam bidang ini mengikuti studi Parasuraman, Zeithaml, dan Berry (Mohammadi \& Mohammadi, 2014).

Mutu layanan dapat diukur dengan menggunakan model SERVQUAL, yang terdiri dari lima indikator, yaitu tangible (berwujud), realiability (keandalan), responsiveness (daya tanggap), assurance (kepastian), dan empathy (empati) (Komariah \& Triatna, 2005). 


\section{Pengaruh Mutu Layanan Akademik terhadap Kepuasan Mahasiswa}

Dyson mengartikan mutu layanan sebagai keluaran yang disampaikan dengan lebih baik dan terstandar melalui sebuah layanan. Kualitas pelayanan di sektor pendidikan khususnya di lembaga pendidikan tinggi adalah aspek fundamental dari keunggulan pendidikan (Malik, 2010). Sedangkan kepuasan mahasiswa merupakan evaluasi emosional berbagai hasil dan pengalaman yang beruhubungan dengan pendidikan yang benar benar mereka peroleh dibandingkan dengan harapan mereka sebelumnya (Sumaedi, 2011).

Mutu layanan berpengaruh besar terhadap kepuasan mahasiswa dalam berbagai aspek. Inti dari kepuasan mahasiswa tergantung pada kualitas mengajar dan lingkungan belajar di institusi sebagai permintaan mahasiswa yang memenuhi syarat dengan baik, pembelajaran dan pengalaman fakultas untuk akademik mereka dan perkembangan profesional (Malik, 2010).

\section{METODOLOGI}

Penelitian ini menggunakan metode explanatory survey. Metode ini dianggap tepat karena penelitian ini dilakukan untuk mengumpulkan informasi faktual melalui penggunaan kuesioner. Responden adalah mahasiswa salah satu universitas di Bandung.

Instrumen pengumpulan data berupa angket model skala likert yang terdiri atas dua bagian. Bagian pertama adalah kuesioner untuk mengukur persepsi responden mengenai mutu layanan akademik yang dijabarkan dari lima indikator yaitu tangible (berwujud), realiability (keandalan), responsiveness (daya tanggap), assurance (kepastian), dan empathy (empati). Bagian ini terdiri atas 25 item. Bagian kedua adalah kuesioner untuk mengukur persepsi responden mengenai kepuasan mahasiswa yang dijabarkan dari tifa indikator yaitu senang, share positive information, dan tidak komplain. Bagian ini terdiri atas 24 item.

Statistik deskriptif menggunakan frekuensi dan persentase yang digunakan untuk memperoleh gambaran tingkat persepsi responden mengenai mutu layanan akademik dan kepuasan mahasiswa. Statistik inferensial menggunakan analisis regresi yang digunakan untuk menguji hipotesis.

\section{HASIL PENELITIAN DAN PEMBAHASAN}

Variabel-variabel yang diteliti pada penelitian ini meliputi dua variabel inti, yaitu Mutu Layanan Akademik (X) dan Kepuasan Mahasiswa (Y). Data dalam penelitian ini didapat dari penyebaran angket (kuesioner) yang disebarkan kepada 348 responden yang merupakan sampel dari jumlah seluruh mahasiswa di salah satu universitas di Bandung.

Gambaran data dari kedua variabel tersebut diperoleh melalui perhitungan frekuensi dan persentase terhadap jawaban responden. Untuk mempermudah dalam mendeskripsikan variabel penelitian, digunakan kriteria tertentu yang mengacu pada frekuensi dan persentase tanggapan responden pada kategori angket. Data yang diperoleh kemudian diolah, maka diperoleh rincian skor dan kedudukan responden berdasarkan urutan angket yang masuk untuk masing-masing variabel.

\section{Mutu Layanan Akademik}

Deskripsi variabel mutu layanan akademik diperoleh melalui perhitungan frekuensi dan persentase terhadap perolehan data variabel mutu layanan akademik.

Hasil pengolahan data menunjukan kenyataan di lapangan, dimana kenyataan di lapangan menggambarkan bahwa tingkat mutu layanan akademik berada pada kategori sedang. Hal ini dibuktikan dengan hasil perhitungan persentase frekuensi jawaban angket dari 348 responden yang menunjukkan hasil sebesar 57,8\%. Hasil perhitungan yang 
diperoleh berdasarkan dari jawaban angket mengenai mutu layanan akademik merupakan penyatuan dari lima indikator mengenai mutu layanan akademik digambarkan pada tabel di bawah ini.

Tabel 1 Mutu Layanan Akademik

\begin{tabular}{|l|c|c|}
\hline \multicolumn{1}{|c|}{ Indikator } & Persentase & Penafsiran \\
\hline Tangible & $53,4 \%$ & Sedang \\
\hline Reliability & $61,1 \%$ & Sedang \\
\hline Responsiveness & $45,7 \%$ & Sedang \\
\hline Assurance & $63,5 \%$ & Sedang \\
\hline Emphaty & $70,5 \%$ & Sedang \\
\hline Rata-rata & $\mathbf{5 7 , 8 \%}$ & Sedang \\
\hline
\end{tabular}

Tabel di atas menunjukkan bahwa indikator tertinggi adalah empathy (empati) dengan persentase $70,5 \%$. Fakta dilapangan ditemukan bahwa personil fakultas bersedia untuk peduli dan memberikan perhatian kepada mahasiswa, contohnya seperti staf fakultas memberikan pelayanan yang baik mengenai beasiswa untuk mahasiswa, namun masih harus terus tingkatkan lagi. Sedangkan indikator terendah adalah indikator responsiveness (daya tanggap) dengan persentase 45,7\%. Fakta dilapangan ditemukan bahwa kurangnya daya tanggap personil fakultas dalam memberikan layanan kepada mahasiswa. Sehingga dapat dimaknai bahwa mutu layanan pada indikator responsiveness (daya tanggap) belum sesuai dengan yang diharapkan.

\section{Kepuasan Mahasiswa}

Berdasarkan hasil penelitian terhadap variabel kepuasan mahasiswa dengan tiga indikator untuk mengukur tingkat kepuasan mahasiswa, yaitu senang, share positive information, dan tidak komplain. Diperoleh hasil pengolahan data yang menggambarkan tingkat kepuasan mahasiswa berada pada kategori sedang dengan persentase 60,4\%, dimana perhitungan tersebut merupakan gabungan dari tiga indikator yang telah disebutkan sebelumnya. Hal ini dijabarkan pada tabel di bawah, sebagai berikut.

Tabel 2 Kepuasan Mahasiswa

\begin{tabular}{|l|c|c|}
\hline \multicolumn{1}{|c|}{ Indikator } & Persentase & Penafsiran \\
\hline Senang & $60,9 \%$ & Sedang \\
\hline Share Positive Information & $56,1 \%$ & Sedang \\
\hline Tidak Komplain & $63,2 \%$ & Sedang \\
\hline Rata-rata & $\mathbf{6 0 , 4 \%}$ & Sedang \\
\hline
\end{tabular}

Berdasarkan tabel di atas menunjukkan bahwa indikator tertinggi adalah indikator tidak komplain dengan persentase $63,2 \%$. Tidak komplain artinya tidak ada keluhan yang berarti terhadap proses pembelajaran, pelayanan administrasi, dan fasilitas yang ada di fakultas. Sedangkan indikator terendah adalah indikator share positive information dengan 56,1\%. Mahasiswa yang puas akan berbagi informasi positif mengenai lembaga pendidikan, baik kepada kerabat, teman, ataupun oranglain. Dapat dimaknai bahwa ketiga indikator tersebut belum sesuai dengan yang diharapkan. 


\section{Pengaruh Mutu Layanan Akademik terhadap Kepuasan Mahasiswa}

Mutu layanan berpengaruh besar terhadap kepuasan mahasiswa dalam berbagai aspek. Inti dari kepuasan mahasiswa tergantung pada kualitas mengajar dan lingkungan belajar di institusi sebagai permintaan mahasiswa yang memenuhi syarat dengan baik, pembelajaran dan pengalaman fakultas untuk akademik mereka dan perkembangan profesional (Malik, 2010).

Persamaan regresi linier sederhana untuk hipotesis variabel mutu layanan akademik terhadap kepuasan mahasiswa adalah: $\hat{Y}=6,089+0,953(\mathrm{X})$. Tanda positif $(+)$ menunjukkan hubungan antara variabel bebas dengan variabel terikat berjalan satu arah, yang artinya setiap peningkatan atau penurunan di satu variabel, akan diikuti oleh peningkatan atau penurunan di satu variabel lainnya, sehingga apabila semakin tinggi mutu layanan akademik, maka semakin tinggi pula kepuasan mahasiswa begitupun sebaliknya.

Perhitungan pengujian hipotesis diperoleh $\mathrm{F}_{\text {hitung }}$ sebesar 31,042 sedangkan $\mathrm{F}_{\text {tabel }}$ dengan tingkat kesalahan $\propto=0,05$ dan $\mathrm{dk}_{\text {reg b/a }}=1$ dan $\mathrm{dk}_{\text {res }}=\mathrm{n}-2=348-2=346$ sebesar 3,868 artinya $F_{\text {hitung }} \geq F_{\text {tabel }}$ yaitu 31,042 >3,868, maka $\mathrm{H}_{0}$ ditolak dan $\mathrm{H}_{1}$ diterima, sehingga dapat disimpulkan bahwa "Terdapat pengaruh positif mutu layanan akademik terhadap kepuasan mahasiswa".

Untuk mengetahui besarnya pengaruh variabel $\mathrm{X}$ terhadap variabel $\mathrm{Y}$, maka digunakan koefisien determinasi (KD). Sebelum menghitung koefisien determinasi maka dilakukan perhitungan koefisien korelasi. Penelitian ini menggunakan Korelasi Product Moment yang dikembangkan oleh Karl Pearson, diperoleh perhitungan koefisien korelasi antar variabel variabel $\mathrm{X}$ dan Variabel $\mathrm{Y}$ sebesar 0,5675 dikonsultasikan dengan tabel Guilford Emerical Rules dengan batas-batas korelasi (r) untuk mengetahui derajat hubungan antara Variabel Mutu Layanan Akademik (X) dengan Variabel Kepuasan Mahasiswa (Y), dikategorikan cukup kuat.

Adapun besarnya pengaruh variabel dalam penelitian ini digunakan untuk menghitung pengaruh Mutu Layanan Akademik (X) terhadap Variabel Kepuasan Mahasiswa (Y) yaitu dengan mencari nilai koefisien determinasi. Nilai koefisien determinasi variabel mutu layanan akademik (X) terhadap kepuasan mahasiswa (Y) yaitu sebesar 32,21\%. Hal ini menunjukkan bahwa kepuasan mahasiswa (Y) dipengaruhi oleh mutu layanan akademik (X) sebesar 32,21 \%, sedangkan sisanya sebesar 67,79\% dipengaruhi oleh faktor lain.

Hasil perhitungan ini menunjukan bahwa terdapat pengaruh yang positif dan signifikan antara mutu layanan akademik terhadap kepuasan mahasiswa.

Analisis kesimpulan penulis dalam permasalahan pengaruh mutu layanan akademik terhadap kepuasan mahasiswa dilakukan dengan melihat hasil uji asumsi dan analisis data pengujian hipotesis. Hasil perhitungan analisis uji asumsi data menunjukan data berdistribusi normal dan homogen. Selanjutnya penulis melakukan uji hipotesis parametrik untuk mengetahui seberapa besar pengaruh mutu layanan akademik terhadap kepuasan mahasiswa.

\section{KESMPULAN}

Berdasarkan hasil penelitian dan pembahasan yang telah dilakukan, maka dapat diambil beberapa kesimpulan seperti yang dijabarkan sebagai berikut :

Tingkat mutu layanan akademik diukur menggunakan 5 indikator yaitu, tangible (berwujud), reliability (keandalan), repponsiveness (daya tanggap), assurance (kepastian), dan empathy (empati), berdasarkan perhitungan dari indikator tersebut, mutu layanan akademik berada pada kategori sedang. Tingkat kepuasan mahasiswa diukur menggunakan 3 indikator yaitu, senang, share positvive information; dan tidak komplain, variabel 
kepuasan mahasiswa berada pada kategori sedang berdasarkan hasil perhitungan dari indikator-indikatornya.

\section{DAFTAR PUSTAKA}

Alma, B. (2003). Pemasaran Stratejik Jasa Pendidikan. Bandung: Alfabeta.

Bakti, I. G., \& Mestari, N. (2011). The Effect of Student Perceived Service Quality and Perceived Price on Student Satisfaction. Management Science and Engineering, 5(1), 88-97.

Dahan, S. M., Taib, M. Y., Zainudin, N. M., \& Ismail, F. (2015). Surveying Users PErception of Academic Library Service Quality: A Case Study in Universiti Malaysia Pahang (UMP) Library. The Journal of Academic Librarianship, 1-6.

Dib, H., \& Alnazer, M. (2013). The Impcat of Service Quality on Student Satisfaction and Behavioral Consequences in Higher Education Serviices. International Journal of Economy, Management, and Social Sciences, 2(6), 285-290.

Elliot, K. M., \& Shin, D. (2002). Student Satisfaction: an alternative approach to assessing this important concept. Journal of Higher Education Policy and Management, 24(2), 198-209.

Hanaysha, J. R., Abdullah, H. H., \& Warokka, A. (2011). Service Quality and Student Satisfaction at Higher Learning Institutions: The Competing Dimensions of Malaysian Universities Competitiveness. Journal of Southeast Asian Research, 1-9.

Ilyas, Y. (2011). Implementasi Manajemen Terpadu (TQM) di Lembaga Pendidikan. 4(1), $1-10$.

Jurkowitsch, S. (2006). Student Satisfaction Model for Austrian Higher Education Providers Considering Aspects of Marketing Communications. Special Edition on Customer Satisfaction - Global Perspective, 2(3), 9-22.

Keshavarzi, A., \& Ahmadi, S. (2013). The Study of Student Educational Satisfaction in Islamic Azad University. Social and Behavioral Sciences, 83, 569-573.

Khosravi, A. A., Poushaneh, K., Roozegar, A., \& Sohrabifard, N. (2013). Determination of Factors Affecting Student Satisfaction of Islamic Azad University. Social and Behavioral Sciences, 84, 579-583.

Komariah, A., \& Triatna, C. (2005). Visionary Leadership Menuju Sekolah Efektif. Jakarta: PT. Bumi Aksara.

Kundi, G. M., \& Khan, M. S. (2014). Impact of Service Quality on Customer Satisfaction in Higher Education Institutions. Industrial Engineering Letters, 4(3), 23-28.

Malik, M. E. (2010). The Impact of Service Quality on Student Satisfaction in Higher Education Insitutes of Punjab. Journal of Management Research, 2(2), 1-11.

Mohammadi, A., \& Mohammadi, J. (2014). Educational Service Quality in Zanjan University of MEdical Sciences from Student Point of View. World Journal of Education, 4(5), 86-93.

Mulyawan, A., \& Juhana, D. (2015). Pengaruh Kualitas Jasa Pendidikan terhadap Kepuasan Mahasiswa di STMIK Mardira Indonesia Bandung. 9(2), 1-15.

Mulyawan, D., \& Shidarta, I. (2014). Determinan Kualitas Layanan Akademik di STMIK Mardira Bandung. Jurnal Komputer dan Bisnis, 8(1), 13-24. 
Negricea, C. I., Edu, T., \& Avram, E. M. (2014). Establishing Influence of Spesific Academic Quality on Student Satisfaction. Social and Behavioral Sciences, 116, 4430-4435.

Saif, N. I. (2014). The Effect of Service Quality on Student Satisfaction: A Field Study for Health Services Administration Students. International Journal of Humanities and Social Science, 4(8), 172-181.

Seng, E. L., \& Ling, T. P. (2013). A Statistical Analysis of Education Service Quality Dimensions on Business School Students Satisfaction. International Education Studies, 6(8), 137.

Smith, G. G., Heindel, A. J., \& Torres-Ayala, A. T. (2008). E-learning commodity or community: Disiplinary diferences between online courses. The Internet and Higher Education, 11(3), 152-159.

Suhardan, D. (2006). Supervisi Bantuan Profesional (Layanan dalam Meningkatkan Mutu Pembelajaran di Era Otonomi Daerah). Bandung: CV Alfabeta .

Sumaedi, S. (2011). The Effect of Student Perceived Service Quality and Perceived Price on Student Satisfaction. Management Science and Engineering, 5(1), 88-97.

Susanto, H. (2014). Pengaruh Layanan Akademik terhadap Kepuasan Mahasiswa. Jurnal Pendidikan Terbuka dan Jarak Jauh, 15(2), 88-98.

Tjiptono, F. (2001). Strategi Pemasaran. Yogyakarta: Penerbit Andi.

Triyanto, \& Latnip, D. P. (2014). Implementasi Penyelenggaraan ISO 9001:2008 dalam Bidang Mutu Layanan Administrasi Akademik. Jurnal Akuntabilitas Manajemen Pendidikan, 1(1), 150-161.

Tuan, M. N. (2012). Effect of Service Quality and Price Fairness on Student Satisfaction. International Journal of Business and Social Science, 3(19), 132-150.

Yousapronpaiboon, K. (2014). SERVQUAL: Measuring higher education service Quality in Thailand. Social and Behavioral Sciences, 116, 1088-1095. 